\title{
Investigations of nanoparticle emissions of two gasoline cars MPI \& DI at stationary part load operation
}

\begin{abstract}
Starting from Euro 6 not only for diesel but also for gasoline vehicles, with direct injection technology (GDI) a solid particle number emissions limit of $6 \times 10^{11} \# / \mathrm{km}$ becomes effective. The limit was temporary extended for GDI to $6 \times 10^{12} \# / \mathrm{km}$. Nuclei of metals as well as organics are suspected to significantly contribute especially to the ultrafine particle size fractions, and thus to the particle number concentration. In the project GasOMeP (Gasoline Organic \& Metal Particulates) metal-nanoparticles (including sub $20 \mathrm{~nm}$ ) from gasoline cars are investigated for different engine technologies. In the present paper some results of basic investigations of nanoparticles from two gasoline cars - an older one with MPI and a never one with DI - are represented. The measurements were performed at vehicle tailpipe, with varying sampling conditions and with different SMPS-systems, which enabled the mobility scanning in different size ranges. The results show that the older vehicle with MPI emits high particle count concentrations. The size distributions are decisively bimodal with high numbers in nuclei mode. In this case, the particle counting below 10 nm yields important information. The emissions of the newer vehicle with DI show no typical uniform shape of particle size distributions and are at lower level, than for the older vehicle. There is no visible nuclei mode and the ultrafine particle concentrations below $10 \mathrm{~nm}$ are insignificant. A sampling with a strongly increased primary dilution has a clear influence on the indicated (higher) particle concentrations.
\end{abstract}

Key words: nanoparticles, emission standards, ambient air limits, health benefits

\section{Emisja nanocząstek z dwóch pojazdów wyposażonych w silniki ZI - MPI i DI w warunkach stacjonarnych przy częściowym obciążeniu}

\begin{abstract}
Poczawszy od normy Euro 6 wprowadzone zostanie ograniczenie emisji czastek stałych do $6 \times 10^{11}$ \#/km nie tylko dla pojazdów wyposażonych $w$ silniki ZS, ale także dla pojazdów z silnikami ZI z bezpośrednim wtryskiem paliwa (GDI). Dopuszczalna liczba czastek stałych emitowanych przez pojazdy wyposażone w silniki GDI była tymczasowo zwiększona do $6 \times 10^{12} \# / k m$. Czastki metali, jak również substancje organiczne prawdopodobnie sa powodem emisji bardzo matych czastek statych, przyczyniajac się do zwiększenia liczby emitowanych czastek statych. W projekcie GasOMeP (czastki organiczne i metalowe z silników benzynowych) badana jest emisja nanocząstek metali (również o średnicy $<20 \mathrm{~nm}$ ) $z$ samochodów wyposażonych $w$ silniki benzynowe różnych generacji. W artykule przedstawiono wyniki badań emisji nanoczastek $z$ dwóch samochodów wyposażonych $w$ silniki benzynowe - starszy z wtryskiem MPI $i$ nowszy z wtryskiem DI. Spaliny pobierano z układu wylotowego pojazdu przy różnych warunkach pomiarowych i z wykorzystaniem urzadzeń do pomiaru emisji cząstek stałych o różnych zakresach pomiarowych. Wyniki badań wskazują, że stężenie cząstek stałych w spalinach starszego pojazdu z wtryskiem MPI jest duże. Rozkłady wielkości maja charakter bimodalny z dużymi wartościami w fazie nukleacji. Wtedy istotny jest pomiar liczby cząstek stałych o średnicy mniejszej niż 10 nm. Emisja z pojazdu z wtryskiem typu DI nie wykazuje typowego jednolitego ksztaltu rozkładu wymiarowego, również liczba czastek stałych jest mniejsza niż z pojazdu starszego. Nie zauważono znaczacej emisji cząstek w fazie nukleacji, a stężenia czastek najmniejszych o średnicy poniżej $10 \mathrm{~nm}$ są nieznaczne. Pobór próbki spalin przy zastosowaniu dużego wspótczynnika rozcieńczenia ma zauważalny wptyw na zwiększenie stężenia czastek stałych
\end{abstract}

Słowa kluczowe: nanoczastki, limity emisji, normy jakości powietrza, korzyści zdrowotne

\section{Introduction}

Vehicle exhaust is known to be a complex mixture of different volatile and non-volatile species often showing a bimodal particle size distribution with a nucleation mode smaller than $20 \mathrm{~nm}$ and a larger accumulation mode that mainly contains aggregates of primary particles. The larger accumulation mode is usually composed of more graphitic soot particles with an elemental carbon (EC) structure, whereas the particles in the nucleation mode are reported to be mainly volatile organics, especially when sulphur is absent from fuel and lubrication oil, [1]. However, recent studies

\section{Wstęp}

Wiadomo, że spaliny z pojazdów są złożoną mieszaniną różnych związków lotnych i nielotnych, często wykazującą dwumodalny rozkład wielkości cząstek w fazie nukleacji mniejszych niż $20 \mathrm{~nm}$ oraz większych cząstek w fazie akumulacji, która głównie składa się z agregatów cząstek pierwotnych. W fazie akumulacyjnej cząstek stałych zazwyczaj zawarte jest więcej cząstek sadzy grafitowej o strukturze węgla pierwiastkowego (EC), podczas gdy cząstki stałe w fazie nukleacji składają się głównie z lotnych substancji organicznych, szczególnie gdy nie ma siarki w paliwie i 
detected also low-volatility particle fractions in the ultrafine size range when sampling was carried out according to PMP protocol at $300{ }^{\circ} \mathrm{C},[2-4]$. These particles are suspected to be nucleated metal oxides originating from metal additives in lubrication oil or fuels $[5,6]$. The formation of this particulate fraction was especially observed when the soot content was low as in idle condition of diesel vehicles. These particles mainly appear in the ultrafine size rage $<23 \mathrm{~nm}$. While the mass contribution of these ultrafine particles in vehicle emissions is very low, their contribution to the number concentration is expected to be significant. Moreover, these ultrafine particles may contribute to the surface composition of the aerosol and have therefore a significant impact on health effects associated with pollution. Thus, knowledge about the amount, chemistry and formation mechanisms of these particles is needed to assess their toxic potential, and to propose effective measures to reduce these emissions.

Studies for gasoline fuelled internal combustion engines pointed out that also this vehicle class can emit remarkable amounts of particles [7, 8].

Especially gasoline direct injection technology (GDI) shows particle number (PN) emissions significantly higher than modern diesel cars equipped with best available DPF technology. Since the trend for gasoline vehicles with GDI technology is increasing, a significant rise in emission is predicted in the near future.

The nanoparticles emissions are produced especially at cold start and warm-up conditions and at a dynamic engine operation [9]. The lube oil contributes to this emission in the sense of number concentrations in nuclei mode and composition $[5,6]$.

The investigations of morphology of the nanoparticles from gasoline direct injection engine revealed principally graphitic structures, which can store some metal oxides in certain conditions and can be overlapped by condensates $[10,11]$.

The investigations in present paper were performed at AFHB (Laboratories for IC-Engines and Exhaust Emission Control of the Berne University of Applied Sciences, Biel $\mathrm{CH}$ ) as a part of the network project GasOMeP, together with the Swiss Research Institutions: EMPA, FHNW and PSI.

\section{Test vehicles, fuel and lubricants}

The comparison of NP-emissions of a vehicle with MPI (older technology) with a recent vehicle with GDI was performed on Renault 18 and Audi A3 (Fig. 1, Tab. 1). The gasoline used was from the Swiss market, RON 95, according to SN EN228. In the present tests the lube oils were not changed and not analyzed.

\section{Test methods and instrumentation}

The vehicles were tested on a chassis dynamometer at constant speeds: Renault 18 at $40 \mathrm{~km} / \mathrm{h}, 2^{\text {nd }}$ gear and Audi A3 at $30 \mathrm{~km} / \mathrm{h}, 2^{\text {nd }}$ gear.

The particle size distributions (PSD) of the nanoparticles were presented in different size spectra with varying sampling conditions: temperature of minidiluter TMD, temperature of thermoconditioner (evaporation tube) TTC oleju smarującego [1]. Jednak najnowsze badania wykazały również frakcje cząstek o niskiej lotności w zakresie najmniejszych wielkości, gdy próbkowanie przeprowadzono zgodnie $\mathrm{z}$ programem PMP $\mathrm{w}$ temperaturze $300{ }^{\circ} \mathrm{C}$ [2-4]. Przypuszczalnie cząstki te są cząstkami tlenków metali pochodzącymi z dodatków metalicznych w oleju smarującym lub paliwie $[5,6]$. Powstawanie tej frakcji cząstek było możliwe do zaobserwowania szczególnie przy małej zawartości sadzy, podobnie jak podczas pracy pojazdów z silnikami ZS na biegu jałowym. Cząstki te występują głównie w zakresie najmniejszych wielkości $(<23 \mathrm{~nm})$. Udział masowy najmniejszych cząstek w emisji pojazdów jest bardzo mały, ale należy się spodziewać ich dużego udziału liczbowego. Ponadto te najmniejsze cząstki mogą wpływać na skład powierzchni aerozolu i w związku z tym znacznie na efekty zdrowotne związane z zanieczyszczeniem powietrza. Dlatego potrzebna jest wiedza na temat ilości, składu chemicznego i mechanizmów tworzenia tych cząstek do oceny ich toksyczności i do zaproponowania skutecznych środków w celu zmniejszenia ich emisji.

Badania wykazały, że pojazdy zasilane silnikami benzynowymi także emitują znaczne ilości cząstek stałych [7, 8]. Szczególnie technologia bezpośredniego wtrysku benzyny (GDI) przyczynia się do emisji większej liczby cząstek stałych (PN) niż w nowoczesnych pojazdach z silnikami ZS, wyposażonych w najlepsze filtry cząstek stałych. Ze względu na zwiększający się udział pojazdów z silnikami GDI przewiduje się znaczące zwiększenie emisji cząstek stałych w najbliższej przy

Emisja nanocząstek jest największa podczas zimnego rozruchu, w warunkach rozgrzewania silnika oraz podczas pracy silnika w warunkach dynamicznych [9]. Olej smarujący wpływa na liczbę i skład cząstek stałych w fazie nukleacji $[5,6]$.

Badania morfologii nanocząstek z silnika wyposażonego w bezpośredni wtrysk benzyny wykazały strukturę zasadniczo grafitową, która w pewnych warunkach może absorbować tlenki metali, a one będą pokryte warstwą kondensatów $[10,11]$.

Badania opisane $\mathrm{w}$ tym artykule przeprowadzono $\mathrm{w}$ laboratorium silników spalinowych i badań emisji spalin Berneńskiego Uniwersytetu Nauk Stosowanych, Biel CH (AFHB), jako część projektu GasOMeP, wraz ze szwajcarskimi instytucjami badawczymi: EMPA, FHNW i PSI.

\section{Badane pojazdy, paliwo oraz olej silnikowy}

Porównanie emisji nanocząstek z pojazdu wyposażonego we wtrysk MPI (starszy) z emisją z pojazdu nowoczesnego z wtryskiem GDI przeprowadzono w odniesieniu do samochodów Renault 18 i Audi A3 (rys. 1, tab. 1). Do badań użyto benzynę z rynku szwajcarskiego, zgodną z normą SN EN228, o liczbie oktanowej badawczej 95 . W tych badaniach oleje smarujące nie były wymieniane, ani analizowane.

\section{Metodyka badań oraz aparatura}

Pojazdy badano na hamowni podwoziowej przy jeździe ze stałą prędkością na drugim biegu: Renault 18 przy 40 $\mathrm{km} / \mathrm{h}$, Audi A3 przy $30 \mathrm{~km} / \mathrm{h}$. 

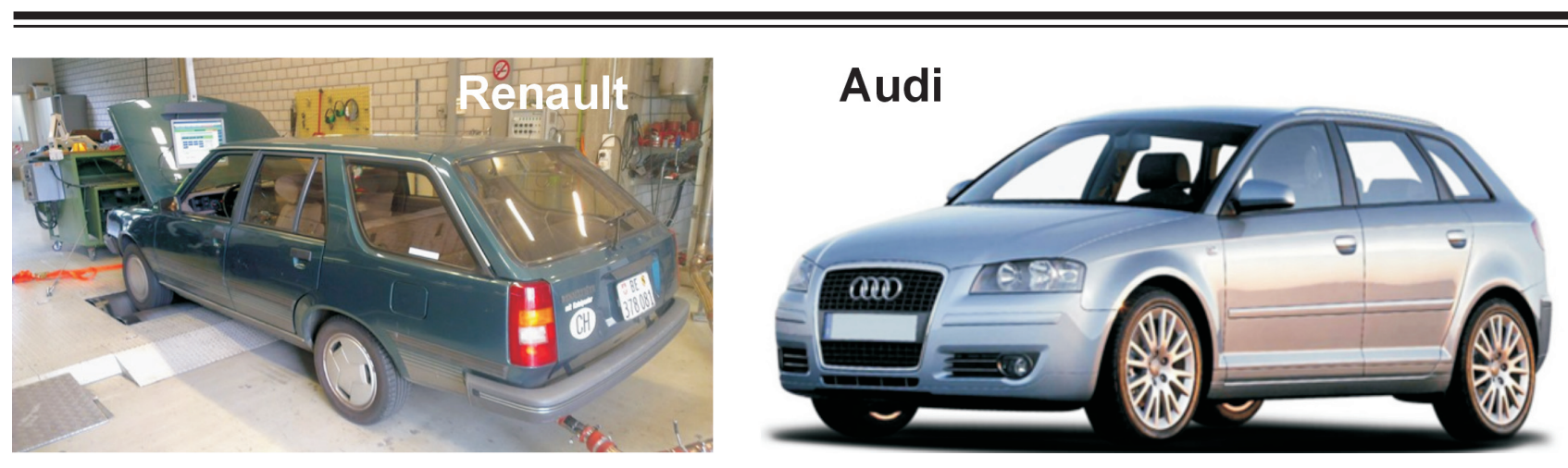

Fig. 1. Gasoline vehicles for research of NP

Rys. 1. Pojazdy z silnikami ZI używane podczas badań emisji nanoczastek

Table 1. Data of vehicles Renault \& Audi

Tabela 1. Dane techniczne pojazdów Renault i Audi

\begin{tabular}{|c|c|c|}
\hline Vehicle/pojazd & Renault 18 Break & Audi A3 2.0 TFSI \\
\hline Engine code/kod silnika & J7T-718 & BWA \\
\hline $\begin{array}{l}\text { Number and arrangement of cylinders/liczba } \\
\text { i uktad cylindrów }\end{array}$ & 4 / in line/4-rzędowy & 4 / in line/4-rzędowy \\
\hline Displacement/objętość skokowa $\left[\mathrm{cm}^{3}\right]$ & 2164 & 1984 \\
\hline Power $/ m o c[\mathrm{~kW}]$ & $74 @ / p r z y 5000$ rpm/obr/min & 147 @ /przy $6000 \mathrm{rpm} / \mathrm{obr} / \mathrm{min}$ \\
\hline Torque/moment obrotowy $[\mathrm{N} \cdot \mathrm{m}]$ & $162 @ / p r z y 2000 \mathrm{rpm} / \mathrm{obr} / \mathrm{min}$ & $280 @ / p r z y 1800 \mathrm{rpm} /$ obr/min \\
\hline Injection type/układ wtryskowy & MPI & DI \\
\hline Curb weight $/$ masa wtasna $[\mathrm{kg}]$ & 1110 & 1530 \\
\hline $\begin{array}{l}\text { Gross vehicle wight/dopuszczalna masa } \\
\text { catkowita }[\mathrm{kg}]\end{array}$ & 1585 & 1920 \\
\hline Drive wheel/rodzaj napędu & Front-wheel drive/przedni & Front-wheel drive/przedni \\
\hline Gearbox/skrzynia biegów & m5/manualna 5 biegów & m6/manualna 6 biegów \\
\hline First registration/data pierwszej rejestracji & 01.04 .1985 & 01.12 .2006 \\
\hline Exhaust/norma emisji spalin & Euro 0 & Euro 4 \\
\hline VIN/numer nadwozia & VF1135B00F 0000505 & WAUZZZ8P17A042987 \\
\hline
\end{tabular}

and the primary and secondary dilution factors DF1 \& DF2.

Following test systems were used:

- roller dynamometer: Schenk 500 G5 60,

- driver conductor system: Tornado, version 3.3,

- CVS dilution system: Horiba CVS-9500T with Roots blower,

- air conditioning in the hall automatic (intake- and dilution air):

- temperature: $20-30{ }^{\circ} \mathrm{C}$,

- humidity: $5.5-12.2 \mathrm{~g} / \mathrm{kg}$.

The driving resistances of the test bench were set according to the legal prescription.

\section{Nanoparticle analysis}

The measurements of NP size distributions were conducted with different SMPS-systems, which enabled different ranges of size analysis:

- SMPS: DMA TSI 3081 \& CPC TSI 3772 (9.8-429 nm),

- nSMPS (AFHB): nDMA TSI 3085 \& CPC TSI 3772 (6.85

$-85 \mathrm{~nm})$,

- nSMPS (EMPA): nDMA TSI 3085 \& CPC TSI 3025 (3-64 $\mathrm{nm})$.
Nanocząstki stałych (PSD) przedstawiono w różnych zakresach wymiarowych, różnych warunkach próbkowania: temperatura w układzie rozcieńczania spalin TMD, temperatura w układzie kondycjonowania (tuba skraplająca) TTC oraz pierwszy i drugi współczynnik rozcieńczenia DF1 i DF2. Użyto następujące urządzenia badawcze:

- hamownia podwoziowa: Schenk 500 G5 60,

- układ sterowania jazdą: Tornado, wersja 3.3,

- układ rozcieńczania CVS: Horiba CVS-9500T z dmuchawą Rootsa,

- układ kondycjonowania pomieszczenia - automatyczny (powietrze dolotowe i rozcieńczania):

- temperatura: $20-30{ }^{\circ} \mathrm{C}$,

- wilgotność: $5,5-12,2 \mathrm{~g} / \mathrm{kg}$.

Opory jazdy stanowiska badawczego ustalono zgodnie z wymogami norm.

\section{Analiza nanocząstek}

Pomiary rozkładu wymiarowego nanocząstek NP przeprowadzono za pomocą różnych urządzeń do pomiaru wymiarów cząstek stałych SMPS, które umożliwiały analizę w różnych zakresach wymiarowych: 
For the dilution and sample preparation an ASET system from Matter Aerosol was used (Fig. 2) (ASET - aerosol sampling \& evaporation tube). This system contains:

- primary dilution air - MD19 tunable minidiluter (Matter Eng. MD19-2E),

- secondary dilution air - dilution of the primary diluted and thermally conditioned measuring gas on the outlet of evaporative tube,

- thermoconditioner (TC) - sample heating at $300{ }^{\circ} \mathrm{C}$.

In all tests the gas sample for the NP-analysis was taken from the undiluted exhaust gas at tailpipe.

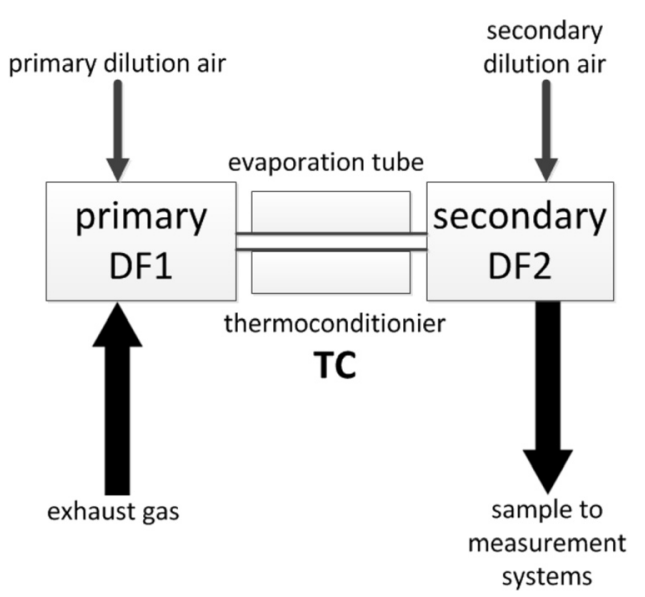

Fig. 2. Set-up of dilution stages and sample preparation for nanoparticle measurements

Rys. 2. Konfiguracja stopni rozcieńczania i przygotowania próbki do pomiarów emisji nanocząstek

\section{Results}

\section{Renault 18}

Figure 3 shows an example of the PSD's obtained with SMPS (9.8-429 nm) and with nSMPS (EMPA; 3-64 nm) at a constant temperature of the minidiluter (TMD) and with varying temperature of the thermoconditioner (TTC). In the nuclei mode, at particle sizes below $10 \mathrm{~nm}$ high peaks
- SMPS: DMA TSI 3081 \& CPC TSI 3772 (9,8-429 nm), - nSMPS (AFHB): nDMA TSI 3085 \& CPC TSI 3772 $(6,85-85 \mathrm{~nm})$,

- nSMPS (EMPA): nDMA TSI 3085 \& CPC TSI 3025 (3-64 $\mathrm{nm})$.

Do rozcieńczania oraz przygotowania próbki spalin użyto układu ASET firmy Matter Aerosol (rys 2). Układ ten zawiera:

- pierwszy stopień rozcieńczenia-MD19 regulowany układ rozcieńczania spalin (Matter Eng. MD19-2E),

- drugi stopień rozcieńczenia - rozcieńczanie spalin przygotowanych odnośnie do składu i temperatury w pierwszym stopniu rozcieńczającym, pobieranych z tuby skraplającej,

- układ kondycjonowania (TC) - podgrzewanie próbki do $300{ }^{\circ} \mathrm{C}$.

We wszystkich próbach badawczych próbka do analizy NP była pobierana z układu wylotowego pojazdu.

\section{Wyniki badań}

\section{Renault 18}

Na rysunku 3 przedstawiono przykładowy rozkład wymiarowy cząstek stałych uzyskany za pomocą układów: SMPS (9,8-429 nm) i nSMPS (EMPA; 3-64 nm) przy stałej temperaturze $\mathrm{w}$ pierwszym stopniu rozcieńczania spalin (TMD) i przy zmiennej temperaturze układu kondycjonowania (TTC). W fazie nukleacji przy średnicach cząstek stałych poniżej $10 \mathrm{~nm}$ zauważalne są duże wartości szczytowe liczby cząstek stałych (PC). Te wartości zmieniają się w zależności od temperatury w układzie kondycjonowania, lecz bez wyraźnego kierunku zmian.

Na rysunku 4 przedstawiono całkowite stężenia cząstek stałych w obu mierzonych zakresach wielkości. Liczba cząstek w fazie nukleacji o średnicach malejących aż do 3 nm (nSMPS) jest o 1 rząd wielkości większa.

Jeśli chodzi o wyniki przy stałej TMD (górna część rys. 4) nie ma wyraźnego wpływu TTC na całkowitą liczbę cząstek stałych (PC) w obu analizowanych zakresach wielkości. Przy stałej TTC (dolna część rys. 4) również nie ma wyraźnej tendencji do zwiększania lub zmniejszania PC o wyższej TMD. Należy zauważyć różnice spowodowane emitowaną i mierzoną dyspersją.

$\mathrm{Na}$ rysunku 5 przedstawiono odpowiedź na pytanie: o ile więcej PC do $64 \mathrm{~nm}$ można zmierzyć, jeśli użyje się układu nSMPS (EMPA) z dodatkowymi wartościami z zakresu od 3 do 9,8 nm? Można stwierdzić, że dodatkowy niższy zakres pomiarowy zawiera ok. dwukrotnie więcej PC niż większy zakres (9,8-64 nm).

Podsumowując:

- w zakresie od 6 do 3 nm zaobserwowano znaczne zwiększenie liczby cząstek stałych, - nie zauważono wyraźnego wpływu TMD lub TTC na wielkości liczby cząstek stałych, a także na wartość szczytową fazy nukleacji,

\footnotetext{
Rys. 3. Rozkłady wymiarowe czastek statych uzyskane za pomoca urządzeń nSMPS i przy różnych temperaturach w układzie kondycjonowania (TC) - Renault $18 ; 40 \mathrm{~km} / \mathrm{h}$; drugi bieg; DF1: 40; DF2: 8
}

\& SMPS - size spectra; variation of the temperature of thermoconditioner \& SMPS - size spectra; variation of the temperature of ther 
of particle count concentration (PC) are visible. These peak values fluctuate at different TTC-scans, but without a clear tendency.

Figure 4 represents the integrated average NP-counts in both measured size ranges. The measurements of the nuclei mode down to $3 \mathrm{~nm}$ (nSMPS) reveal clearly higher PC's up to 1 order of magnitude.

Regarding the results at constant TMD (upper part of the figure) there is no clear influence of TTC on the summary particle counts (PC) in both analyzed size ranges. At constant TTC (lower part of the figure) there is also no clear tendency of increasing, or reducing PC with higher TMD. It must be supposed, that the indicated differences are caused by the emitting and measuring dispersion.

Figure 5 illustrates the answer to the question: how much more PC can we measure up to $64 \mathrm{~nm}$ if we use the nSMPS (EMPA)-system with the supplementary information from 3 to $9.8 \mathrm{~nm}$ ? It can be concluded, that the supplementary lowest size spectrum contains approximately double of PC of the higher spectrum $(9.8-64 \mathrm{~nm})$.

It can be summarized:

- egarding from 6 to $3 \mathrm{~nm}$ there is an considerable increase of PC-concentrations,

- here is no clear tendency of TMD, or of TTC on the integral PC's and also on the peak-values in nuclei mode,

- he lowest measured size range 3 to $9.8 \mathrm{~nm}$ contains up to 3 times so much PC's, as the higher size range 9.8 to $64 \mathrm{~nm}$.

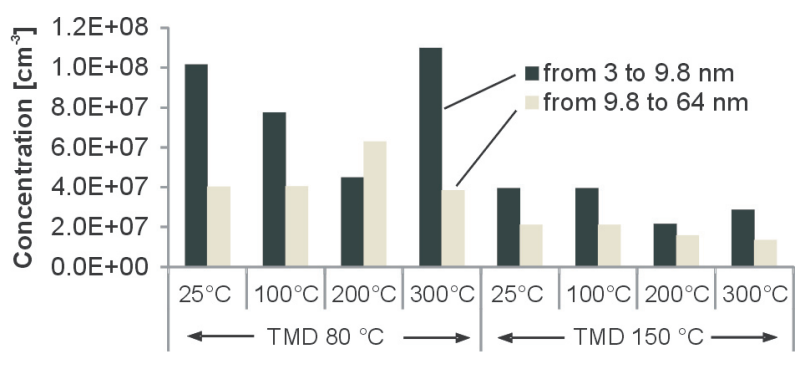

$\mathrm{T}_{\mathrm{TC}}$ temperature of thermoconditioner [ ${ }^{\circ} \mathrm{C}$ ]

Fig. 5. Comparison of integral values of nSMPS (3-64 nm; variation of the temperature of thermoconditioner (TC) and minidiluter (MD) Renault 18; 40 km/h; 2. gear; DF1: 40; DF2: 8. nSMPS (EMPA)

Rys. 5. Porównanie całkowitego stężenia czastek statych dla zakresu wymiarowego nSMPS (3-64 $\mathrm{nm}$ ) w różnych układach kondycjonowania (TC) i rozcieńczania (MD) - Renault 18; $40 \mathrm{~km} / \mathrm{h}$; drugi bieg; DF1: 40; DF2: 8, nSMPS (EMPA)

Analogous test series were performed with a significantly higher primary dilution DF1 $=300$. This higher dilution causes higher PC-concentration peak-values in nuclei mode (up to 1 order of magnitude). Other statements are similar, like for the previous DF1 $=40$ (mentioned above).

Figure 6 gives an example of PSD's measured with nSMPS and with SMPS with both dilution factors DF1 $=40$ and DF1 $=300$. The higher primary dilution causes higher integrated PC in lower size range (nSMPS) and lower integrated $\mathrm{PC}$ in the higher size range (SMPS). The reasons for the higher PC-peaks in nuclei mode with higher primary
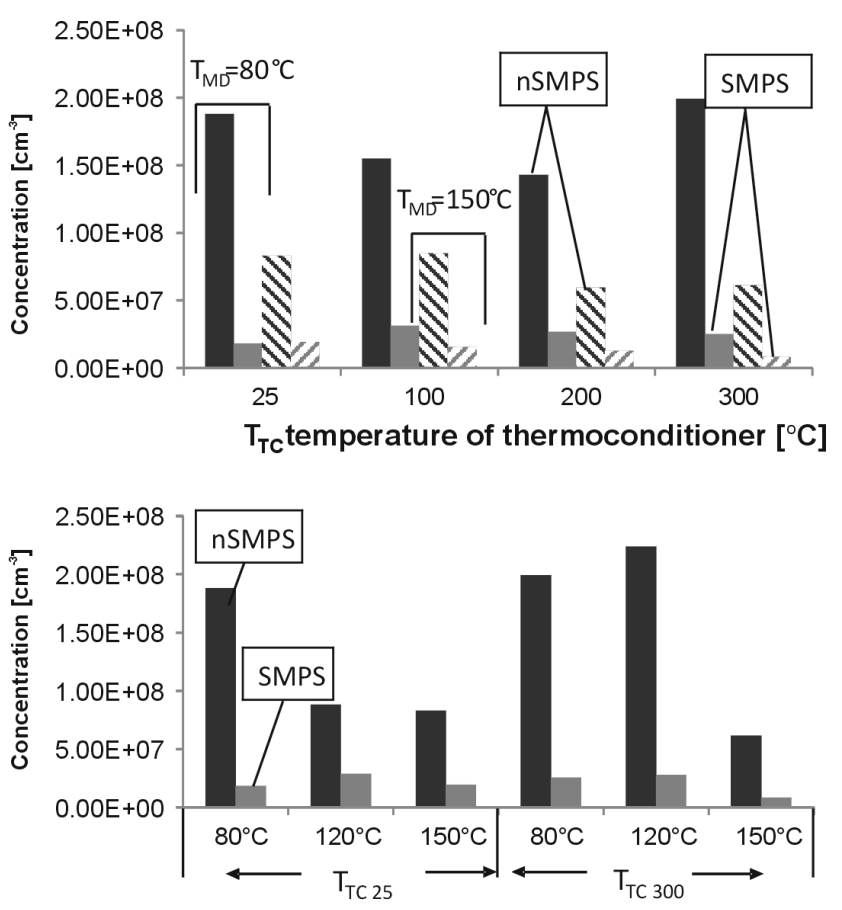

$\mathrm{T}_{\mathrm{MD}}$ temperature of minidiluter [ $\left.{ }^{\circ} \mathrm{C}\right]$

Fig. 4. Comparison of integral values of nSMPS (3-64 nm) \& SMPS $(10-429 \mathrm{~nm})$; variation of the temperature of thermoconditioner (TC) and minidiluter (MD) - Renault 18; $40 \mathrm{~km} / \mathrm{h} ; 2$. gear; DF1: 40; DF2: 8, nSMPS (EMPA)

Rys. 4. Porównanie całkowitego stężenia czastek statych dla zakresów wymiarowych nSMPS (3-64 nm) i SMPS (10-429 nm) w różnych temperaturach uktadu kondycjonowania (TC) i układu rozcieńczania (MD) - Renault 18; $40 \mathrm{~km} / \mathrm{h}$; drugi bieg; DF1: 40; DF2: 8, nSMPS (EMPA)

- w przedziale zawierającym najmniejsze cząstki stałe o wymiarach od 3 do 9,8 nm jest do 3 razy więcej cząstek stałych niż w przedziale od 9,8 do $64 \mathrm{~nm}$.

Analogiczne pomiary przeprowadzono przy znacznie większym współczynniku rozcieńczenia spalin DF1 $=300$. Po zwiększeniu stopnia rozcieńczenia zaobserwowano większą wartość szczytowego stężenia PC w fazie nukleacji (nawet o jeden rząd). Pozostałe obserwacje są podobne jak w poprzednim przypadku, przy DF $1=40$ (wymienione powyżej)

Przykład rozkładu wymiarowego PSD’s zarejestrowanego za pomocą układu SMPS i nSMPS ze współczynnikami rozcieńczenia $\mathrm{DF} 1=40$ i DF1 $=300$ przedstawiono na rys. 6 . Większa wartość pierwszego stopnia rozcieńczenia powoduje większą wartość zakumulowaną PC w mniejszym zakresie wymiarowym (nSMPS) i mniejszą wartość zakumulowaną PC w większym zakresie pomiarowym (SMPS). Przyczyny większych chwilowych wartości PC w fazie nukleacji przy zastosowaniu większego współczynnika rozcieńczenia DF1 można wytłumaczyć większą szybkością aglomeracji i mniejszymi stratami dyfuzyjnymi.

$\mathrm{Na}$ rysunku 7 przedstawiono przykład rozkładu wymiarowego cząstek stałych PSD zmierzonego za pomocą różnych urządzeń pomiarowych w różnych zakresach wielkości cząstek stałych. Wykazano, że liczba cząstek w najmniejszym przedziale wielkości "x" (3-6,85 nm) wynosi 
dilution DF1 can be explained with lower agglomeration speed and lower diffusion losses.

Figure 7 shows an example of PSD's measured with different systems in different size ranges. It is demonstrated, that the particle counts in the lowest size range " $x$ " (3-6.85 $\mathrm{nm}$ ) take the biggest share of $68 \%$ of the entire measured size range (3-429 $\mathrm{nm})$.

The traditional size range " $\mathrm{z}$ " (10-429 nm), which is sufficient for the actual legislation of Diesel engines (23-300 $\mathrm{nm}$ ) contains in this example only $22 \%$ of emitted particle counts.
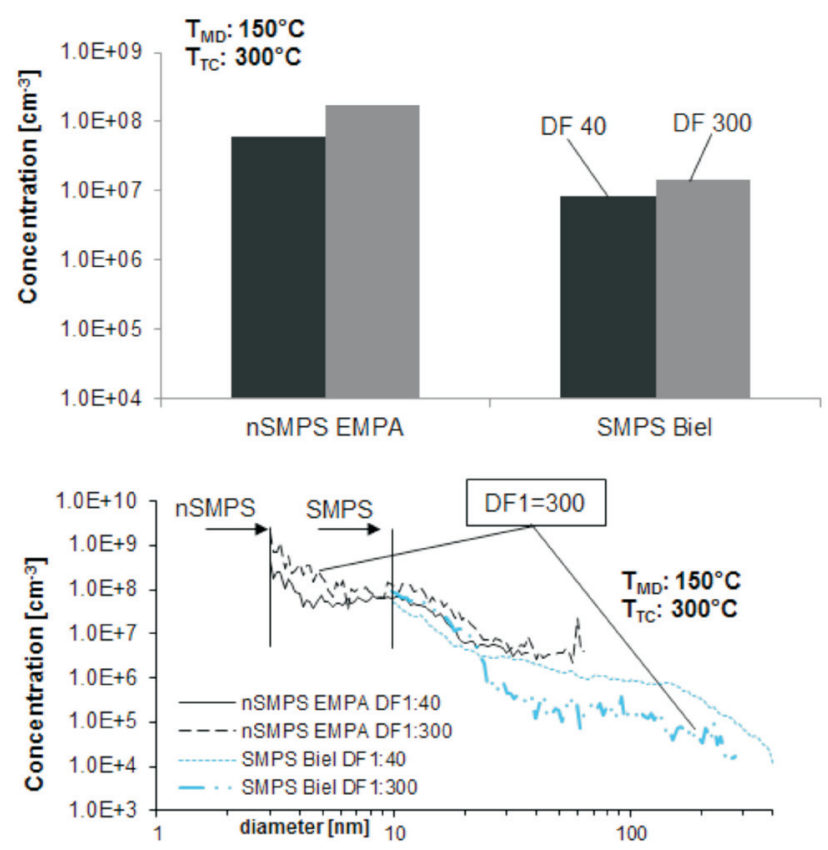

Fig. 6. Comparison of SMPS \& nSMPS at DF1:40 \& DF1:300; temperature of thermoconditioner (TC) and of minidiluter (MD) constant - Renault 18; 40 km/h; 2. gear; DF2: 8

Rys. 6. Porównanie stężenia cząstek statych dla zakresu wymiarowego SMPS \& nSMPS; współczynniki rozcieńczenia DF1:40 i DF1:300; stałe temperatury układu kondycjonowania (TC) i układu rozcieńczania (MD) - Renault 18; $40 \mathrm{~km} / \mathrm{h}$; drugi bieg; DF2: 8

\section{Audi A3}

All NP-measurements on this vehicle were performed with the nSMPS(AFHB) in the size spectrum 6.8-85 $\mathrm{nm}$.

Figure 8 shows an example of PSD's at constant temperature of the thermoconditioner $\mathrm{TTC}=300{ }^{\circ} \mathrm{C}$ and with varying temperature of the minidiluter TMD. The NP-emissions of this vehicle at this part load operating point are very low, nearly at ambient level. There are some sporadic peaks of NP count concentrations.

Figure 9 represents the integrated average PC's: with increasing TTC in the upper part and with increasing TMD in the lower part of the figures. There are no clear tendencies of influences of TMD and TTC on the emissions.

Figure 10 shows that the PC's in the size range $(6.8-9.8 \mathrm{~nm})$ are mostly in lower magnitude than the
$68 \%$, tj. najwięcej w całym zakresie mierzonych wielkości (3-429 $\mathrm{nm})$.

Tradycyjny przedział wielkości “z” (10-429 nm), który jest wystarczający do badań homologacyjnych pojazdów z silnikami ZS (23-300 nm) w analizowanym przypadku zawiera tylko $22 \%$ łącznej liczby wyemitowanych cząstek stałych.
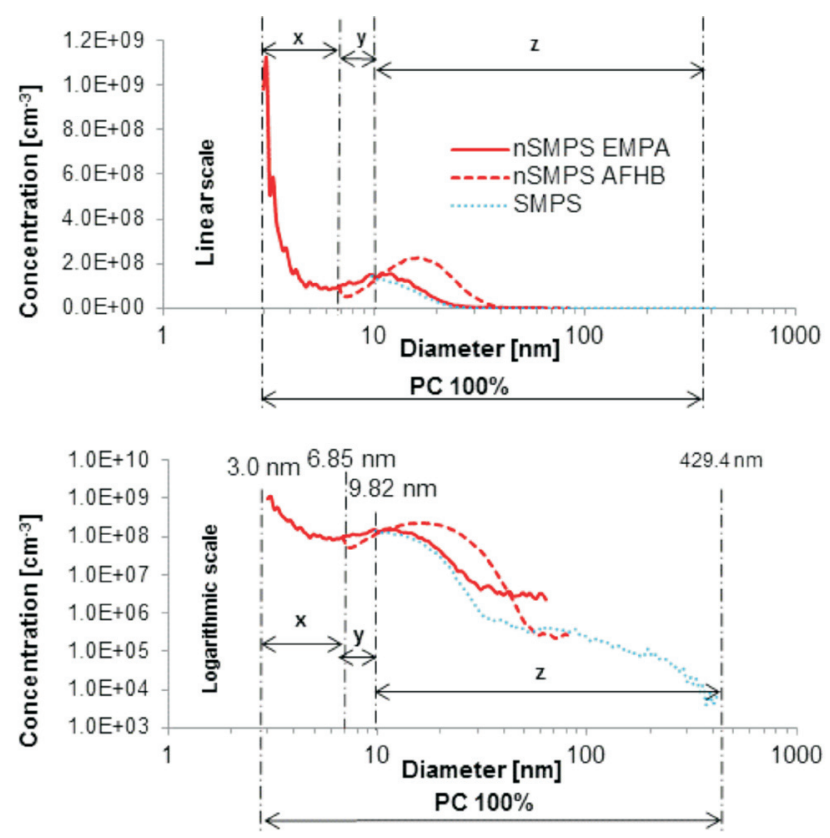

Fig. 7. Particles counts in different size ranges; Renault $18 ; 40 \mathrm{~km} / \mathrm{h} ; 2$. gear; DF 1:40; DF2:8; TMD $=80^{\circ} \mathrm{C} ; \mathrm{TTC}=100^{\circ} \mathrm{C}$

Rys. 7. Liczba czastek statych $w$ różnych zakresach wymiarowych; Renault 18; $40 \mathrm{~km} / \mathrm{h}$; drugi bieg; DF1:40; DF2:8; TMD $=80^{\circ} \mathrm{C}$;

$$
\operatorname{TTC}=100^{\circ} \mathrm{C}
$$

\section{Audi A3}

Wszystkie pomiary liczby nanocząstek odnośnie do tego pojazdu przeprowadzono, wykorzystując nSMPS(AFHB) z zakresem wymiarowym 6,8-85 $\mathrm{nm}$.

Na rysunku 8 przedstawiono przykład rozkładu wymiarowego cząstek stałych PSD przy stałej temperaturze układu kondycjonowania $\mathrm{TTC}=300{ }^{\circ} \mathrm{C}$ i przy zmiennej tempera-

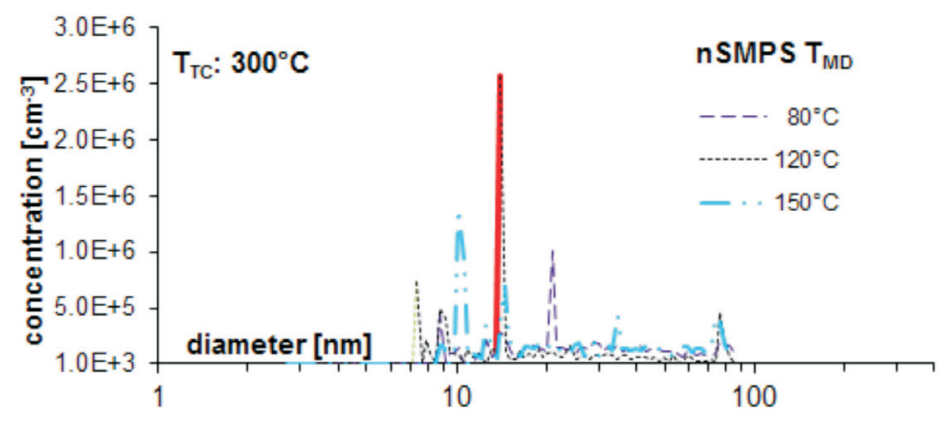

Fig. 8. nSMPS - size spectra; variation of the temperature of minidiluter (MD) - Audi A3 30 km/h; 2. gear; DF1: 300; DF2: 3

Rys. 8. Rozkład wymiarowy cząstek statych uzyskany za pomoca urządzeń nSMPS przy różnych temperaturach w układzie rozcieńczania (MD) - Audi A3; $30 \mathrm{~km} / \mathrm{h}$; drugi bieg; DF1: 300; DF2: 3 

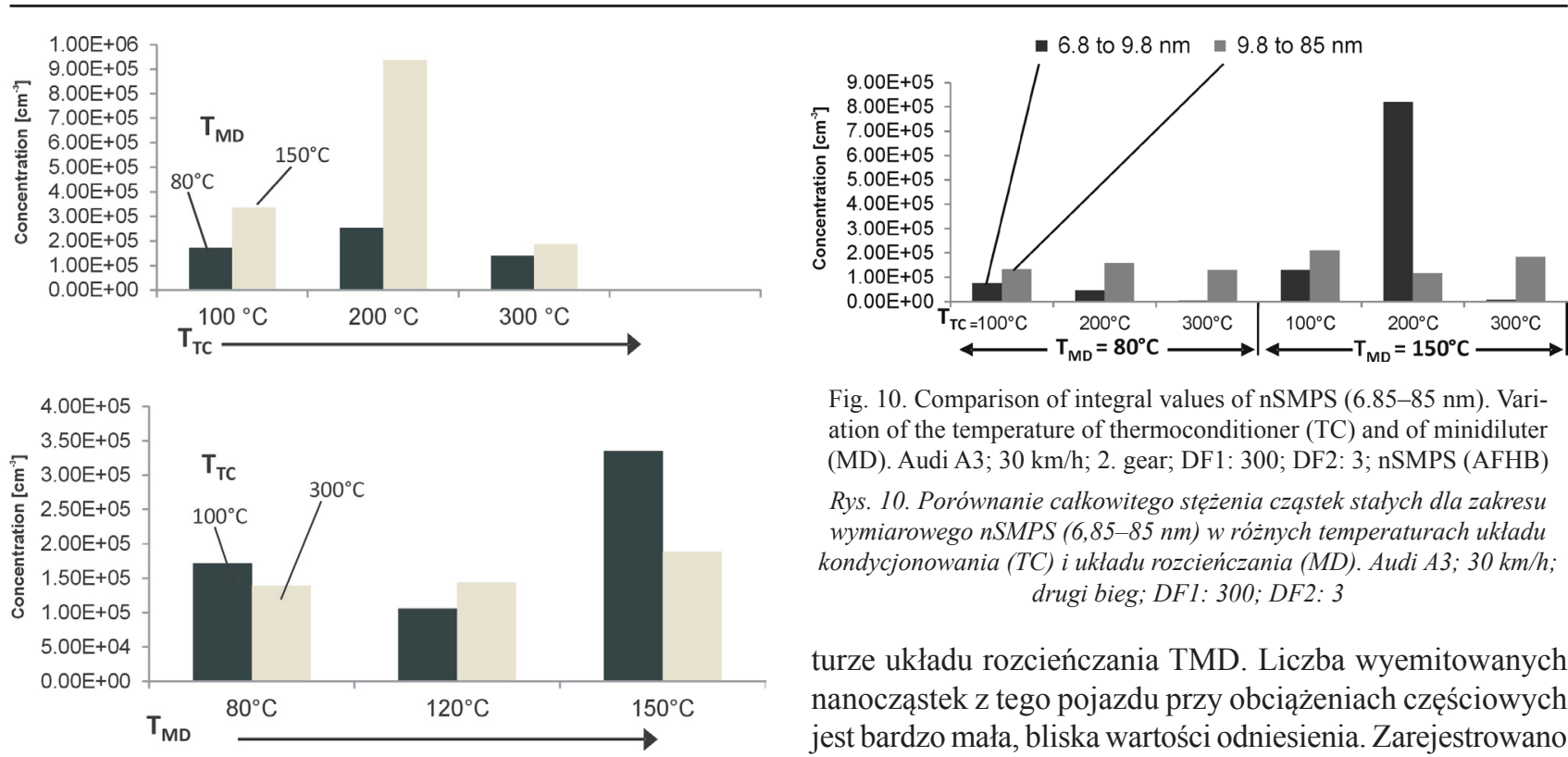

Fig. 9. Comparison of integral values of nSMPS (6.85-85 nm); variation of the temperature of thermoconditioner (TC) and of minidiluter (MD)

- Audi A3; 30 km/h; 2. gear; DF1: 300; DF2: 3; nSMPS AFHB

Rys. 9. Porównanie całkowitego stężenia czastek statych dla zakresu wymiarowego nSMPS $(6,85-85 \mathrm{~nm})$ w różnych temperaturach układu kondycjonowania (TC) i układu rozcieńczania (MD) - Audi A3; 30 $\mathrm{km} / \mathrm{h}$; drugi bieg; DF1: 300; DF2: 3

PC's in the higher size range $(9.8-85 \mathrm{~nm})$. Because of the very low emission level and because of the sporadic emission peaks (no regular PSD's) there is a large dispersion and no clear tendency of these results.
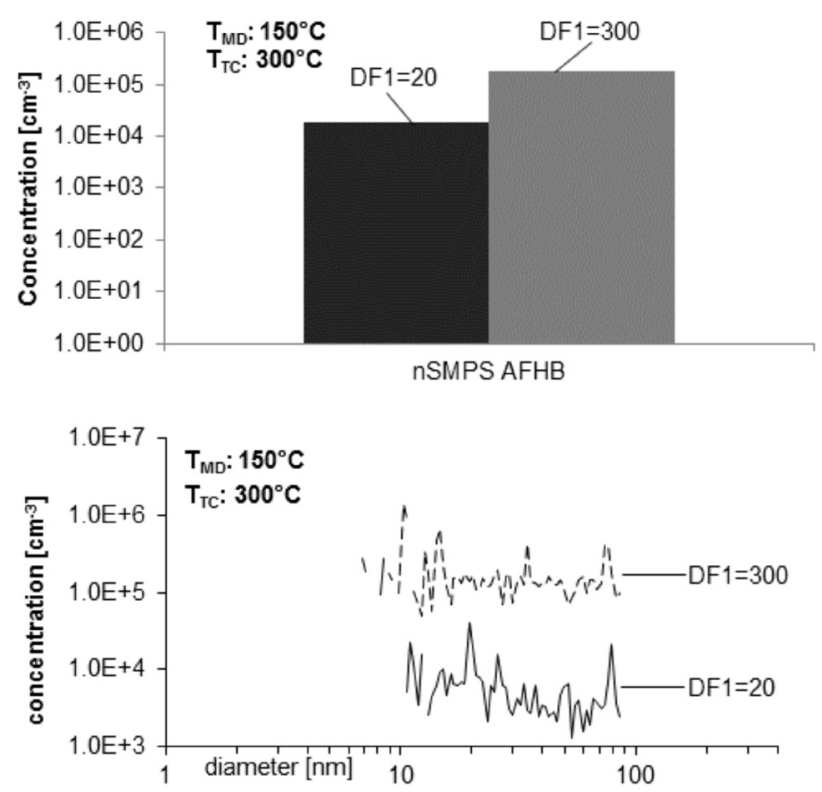

Fig. 11. Comparison of nSMPS at DF1:20 \& DF1:300; temperature of thermoconditioner (TC) and of minidiluter (MD) constant - Audi A3; $30 \mathrm{~km} / \mathrm{h}$; 2. gear; DF1: 20 \& 300; DF2: 3; nSMPS (AFHB)

Rys. 11. Porównanie całkowitego stężenia cząstek statych dla zakresu wymiarowego nSMPS; współczynniki rozcieńczenia DF1:20 i DF1:300. Stałe temperatury układu kondycjonowania (TC) i układu rozcieńczania (MD) - Audi A3; $30 \mathrm{~km} / \mathrm{h}$; drugi bieg; DF1: 20 i 300; DF2: 3

Fig. 10. Comparison of integral values of nSMPS (6.85-85 nm). Variation of the temperature of thermoconditioner (TC) and of minidiluter (MD). Audi A3; 30 km/h; 2. gear; DF1: 300; DF2: 3; nSMPS (AFHB)

Rys. 10. Porównanie całkowitego stężenia cząstek statych dla zakresu wymiarowego $n S M P S(6,85-85 \mathrm{~nm})$ w różnych temperaturach układu kondycjonowania (TC) i układu rozcieńczania (MD). Audi A3; $30 \mathrm{~km} / \mathrm{h}$; drugi bieg; DF1: 300; DF2: 3

turze układu rozcieńczania TMD. Liczba wyemitowanych nanocząstek $\mathrm{z}$ tego pojazdu przy obciążeniach częściowych jest bardzo mała, bliska wartości odniesienia. Zarejestrowano kilka wartości szczytowych stężenia nanocząstek.

Na rysunku 9 przedstawiono średnią wartość liczby zakumulowanych cząstek PC: wraz ze zwiększaniem TTC - górna część rys. 9 - i ze zwiększaniem TMD - dolna część rys. 9. Nie zauważono żadnych tendencji wpływu TMD i TTC na emisję.

$\mathrm{Z}$ analizy rysunku 10 wynika, że liczba cząstek stałych w przedziale wymiarowym $6,8-9,8$ nm osiąga zwykle mniejsze wartości niż PC w większym przedziale wymiarowym 9,8-85 nm. Z powodu bardzo małej wartości emisji oraz sporadycznych wzrostów wartości (niejednolity rozkład wymiarowy), występuje duża niejednorodność, przez co nie można zauważyć wyraźnego kierunku zmian dotyczącego wyników pomiarów.
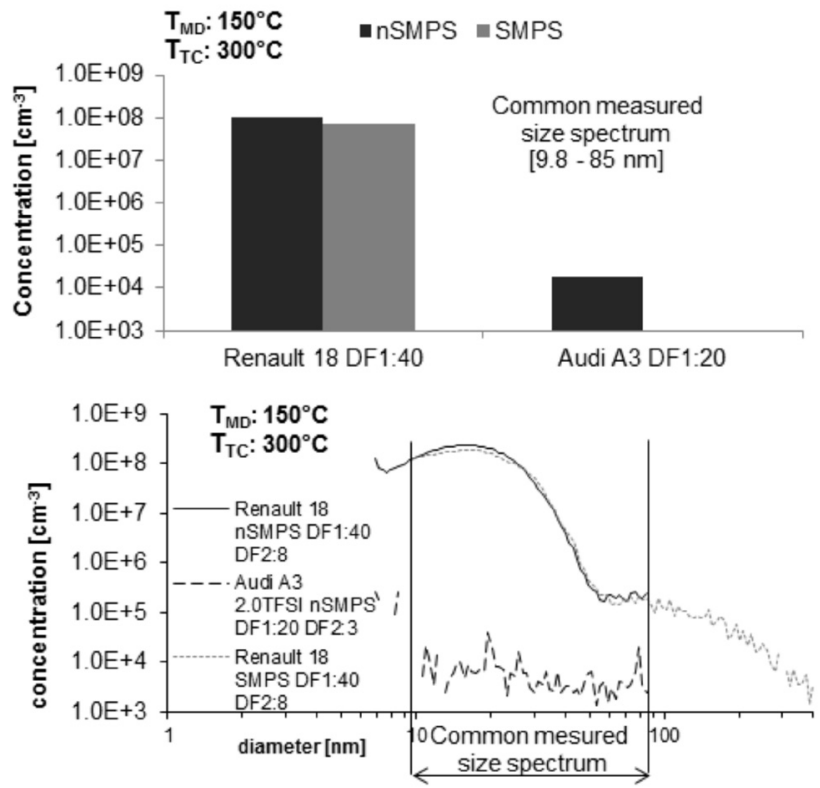

Fig. 12. Comparison of NP-emissions for Audi at $30 \mathrm{~km} / \mathrm{h}$ and Renault at $40 \mathrm{~km} / \mathrm{h}$; SMPS \& nSMPS

Rys. 12. Porównanie stężenia nanocząstek NP - Audi przy $30 \mathrm{~km} / \mathrm{h}$ $i$ Renault przy $40 \mathrm{~km} / \mathrm{h}$; SMPS i nSMPS 
Test with lower primary dilution DF1 $=20$ were also performed with this vehicle. Figure 11 demonstrates the higher average NP-emission level with DF1 $=300$. Also lower particle sizes are visible with the higher dilution DF1 $=300$. It can be followed that the primary dilution DF1 has more influence on the measured NP-emissions than the varied temperatures TMD and TTC.

Figure 12 represents an example of comparisons of NP-emissions of both vehicles. The older model with MPI emits at the stationary part load operation up to 3.5 orders of magnitude more nanoparticles. The principal reason for that is the higher wear and higher lubes oil consumption of the engine.

\section{Conclusions}

The most important statements can be summarized as follows:

- the older model with MPI emits at the stationary part load opera tion up to 3.5 orders of magnitude more nanoparticles,

- for the higher-emitting vehicle regarding to the lowest particle sizes ( 3 to $9 \mathrm{~nm}$ ) there is a considerable increase of PC-concentrations,

- an example for the higher emitting vehicle shows that the lowest size range $(3-6.85 \mathrm{~nm})$ takes the biggest share of $68 \%$ of PC's and the highest size range $(10-429 \mathrm{~nm})$ takes the smallest share, only $22 \%$ of the entire measured size range $(3-429 \mathrm{~nm})$,

- for the low-emitting vehicle there are sporadic NP-emission peaks in the nuclei mode $(6.8-9.8 \mathrm{~nm})$ and there is no clear relationship of the PC's in this mode and in the higher sizerange $(9.8-85 \mathrm{~nm})$,

- for both vehicles there is no clear tendency of TMD, or of TTC on the integral PC's and also on the peak-values in nuclei mode,

- for both vehicles the higher primary dilution DF $1=300$ causes higher NP-emission - the supposed reasons are: lower agglomeration speed and lower diffusion losses of the aerosols,

- it can be followed that the primary dilution DF1 has more influence on the measured NP-emissions than the varied temperatures TMD and TTC.

\section{Acknowledgements}

The authors want to express their gratitude to the institutions, which financially supported the activities: Swiss Federal Office of Environment, Swiss Federal Office of Energy, Swiss Oil and Swiss Lubes. For technical discussions, inspirations and help thanks are due to the GasOMeP partners: Dr. Norbert Heeb, EMPA; Prof. Dr. Heinz Burtscher, FHNW and Dr. André Prévot, PSI.
Podczas badań tego pojazdu zastosowano także mniejszy współczynnik rozcieńczenia DF1 $=20$. Większą emisję nanocząstek zauważono przy zastosowaniu większego współczynnika rozcieńczenia DF1 = 300 (rys. 11). Przy jego zastosowaniu zauważono również zmniejszenie rozmiarów cząstek stałych. Można stwierdzić, że współczynnik rozcieńczenia DF1 ma większy wpływ na zmierzoną wartość stężenia nanocząstek niż zmiany temperatur TMD i TTC.

Na rysunku 12 przedstawiono przykładowe porównanie stężenia nanocząstek z obu pojzadów. Starszy pojazd $\mathrm{z}$ wtryskiem MPI podczas badań stanowiskowych w warunkach obciążeń częściowych emituje nawet o 3,5 rzędu wartości więcej nanocząstek. Główną przyczyną tego stanu jest większe zużycie silnika, powodujące większe zużycie oleju smarującego.

\section{Wnioski}

Najważniejsze obserwacje można podsumować następująco:

- starszy pojazd z wtryskiem MPI podczas badań stanowiskowych w warunkach obciążeń częściowych emituje nawet o 3,5 rzędu wartości więcej nanocząstek,

- w odniesieniu do pojazdu emitującego więcej cząstek stałych znaczne zwiększenie emisji zaobserwowano w zakresie najmniejszych rozmiarów cząstek (3-9 nm),

- przykładowo pojazd emitujący większą liczbę cząstek stałych - udział najmniejszych cząstek stałych $(3-6,85 \mathrm{~nm})$ jest największy i wynosi $68 \%$ PC, natomiast największy zakres wymiarowy (10-429 nm) ma najmniejszy udział, wynoszący $22 \%$ w całkowitej emisji z zakresu 3-429 nm,

- dla pojazdu emitującego mniej cząstek stałych zauważalne są nieliczne wzrosty wartości szczytowych stężenia cząstek stałych w fazie nukleacji $(6,8-9,8 \mathrm{~nm})$ i nie można wskazać wyraźnych zależności między liczbą cząstek stałych w tej fazie i w większych zakresach wymiarowych $(9,8-85 \mathrm{~nm})$,

- dla obu pojazdów nie zauważono wyraźnej tendencji wpływu temperatur TMD lub TTC na całkowitą liczbę cząstek stałych, ani na wartości szczytowe udziału fazy nukleacji,

- w odniesieniu do obu pojazdów większy współczynnik rozcieńczenia DF1 = 300 przyczynia się do zwiększenia liczby cząstek stałych; prawdopodobne przyczyny to: mniejsza prędkość łączenia cząstek stałych i mniejsze straty dyfuzji aerozoli,

- można stwierdzić, że współczynnik rozcieńczenia DF1 ma większy wpływ na zmierzoną liczbę cząstek stałych niż zmiany temperatur TMD i TTC.

\section{Podziękowania}

Autorzy wyrażają wdzięczność instytucjom, które finansowo wspierały ich działalność: Szwajcarskiemu Federalnemu Urzędowi Środowiska, Szwajcarskiemu Federalnemu Urzędowi Energii, Swiss Oil oraz Swiss Lubes. Za dyskusje techniczne, inspiracje i pomoc podziękowania dla partnerów GasOMeP: dr. Norberta Heeb, EMPA; prof. dr. Heinza Burtschera, FHNW i dr. André Prévota, PSI. 


\section{Definitions end abbreviations/oznaczenia i skróty}

AFHB Abgasprüfstelle FH Biel, CH/laboratorium silników spalinowych i badań emisji spalin Berneńskiego Uniwersytetu Nauk Stosowanych Biel

ASET Aerosol Sampling \& Evaporation Tube/uktad próbkowania i odparowywania

BAFU Bundesamt für Umwelt, (see FOEN)/Niemiecki Urząd Ochrony Środowiska, (zob. FOEN)

CLA chemiluminescent analyzer/analizator chemiluminescencyjny

CPC condensation particle counter/uktad zliczania czastek skondensowanych

CVS constant volume sampling/układ rozcieńczający spaliny powietrzem o stałym natężeniu przepływu

DF dilution factor/współczynnik rozcieńczenia

DI Direct Injection/wtrysk bezpośredni

DMA differential mobility analyzer/urzadzenie do pomiaru rozktadu wymiarowego czastek statych

EC Elemental Carbon/wegiel pierwiastkowy

EMPA Eidgenössische Material Prüf- und Forschungsanstalt/ Federalny Instytut Badań i Rozwoju Materiałów
FHNW Fachhochschule Nord-West Schweiz/Pótnocno-Zachodnia Wyższa Szkoła

FOEN Federal Office for Environment/Federalny Urzad Ochrony Środowiska

GDI gasoline direct injection/wtrysk bezpośredni benzyny

MD Minidiluter/układ rozcieńczania spalin

MFS mass flow sensor/czujnik masowego natężenia przepływu

NP Nanoparticles/nanoczastki $<999 \mathrm{~nm}$

nSMPS nano SMPS/urzadzenie do pomiaru rozktadu wymiarowego nanoczastek

PC particle counts (integrated)/czastki state

PMP Particle Measuring Program/program pomiaru czastek statych

PN particle numbers/liczba czastek statych

PSD particle size distribution/rozktad wymiarowy czastek statych

PSI Paul Scherrer Institute/Instytut Paula Scherrera

SMPS scanning mobility particle sizer/urzadzenie do pomiaru rozkładu wymiarowego czastek statych

SP sampling position/miejsce poboru spalin

TC Thermoconditioner/uktad kondycjonowania

\section{Bibliography/Literatura}

[1] Sgro L.A. et al.: Investigating the origin of nuclei particles in GDI engine exhausts. Combustion and Flame, 2012. 159(4), p. $1687-1692$.

[2] Mayer A., Czerwinski J., Ulrich A., Mooney J.J.: Metal-Oxide Particles in Combustion Engine Exhaust. SAE Technical Paper 2010-01-0792.

[3] Mayer A., Czerwinski J., Kasper M., Ulrich A., Mooney J.J.: Metal Oxide Particle Emissions from Diesel and Petrol Engines. SAE Technical Paper 2012-01-0841.

[4] Ulrich A. et al.: Particle and metal emissions of diesel and gasoline engines are particle filters appropriate measures? Proceedings of the 16th ETH Conference on Combustion Generated Nanoparticles 2012.

[5] Buchholz B.A., Dibble R.W., Rich D., Cheng A.S. (ed).: Quantifying the contribution of lubrication oil carbon to particulate emissions from a diesel engine. SAE Technical Paper 2003-01-1987.

[6] Sonntag D.B., Bailey Ch.R., Fulper C.R., Baldauf R.W.: Contribution of Lubricating Oil to Particulate Matter Emissions from Light-Duty Gasoline Vehicles in Kansas City. Environment Science \& Technology, 27. Febr. 2012.

[7] Bach C.: Emissionsvergleich verschiedener Antriebsarten in aktuellen Personenwagen. Untersuchung der Emissionen von

Prof. Jan Czerwiński, DEng. - Laboratorium for IC-Engines and Exhaust Gas Control, University of Applied Sciences Biel-Bienne, Switzerland.

Prof. dr Jan Czerwiński - Laboratorium Silników Spalinowych i Emisji Spalin, Uniwersytet Nauk Stosowanych w Biel-Bienne, Szwajcaria. e-mail: jan.czerwinski@bfh.ch

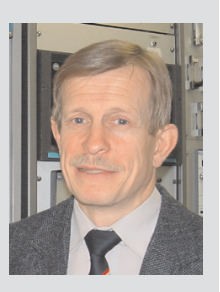

Pierre Comte - AFHB, University of Applied Sciences, Biel-Bienne, Switzerland.

Pierre Comte - Uniwersytet Nauk Stosowanych, Biel-Bienne, Szwajcaria.

e-mail: pierre.comte@bfh.ch aktuellen Personenwagen mit konventionellen und direkteingespritzten Benzinmotoren, Dieselmotoren mit und ohne Partikelfilter, sowie Erdgasmotoren. (Empa Final Report for Novatlantis and Bundesamt für Umwelt BAFU,), in Empa Report 2007 (Novatlantis).

[8] Bielaczyc P., Szczotka A., Woodburn J.: An overview of particulate matter emissions from modern light duty vehicles. Combustion Engines, No. 2/2013 (153), 101-108. ISSN 01380346.

[9] Chan T.W., Meloche E., Kubsh J., Brezny R., Rosenblatt D., Rideout G.: Impact of Ambient Temperature on Gaseous and Particle Emissions from a Direct Injection Gasoline Vehicle and its Implications on Particle Filtration. SAE Technical Paper 2013-01-0527, Detroit, April 2013.

[10] Mathis U., Kaegi R., Mohr M., Zenobi R.: TEM analysis of volatile nanoparticles from particle trap equipped diesel and direct-injection spark-ignition vehicles. Atmospheric Environment 38 (2004) 4347-4355, april 2004.

[11] Lee K.O., Seong H., Sakai St., Hageman M., Rothamer D.: Detailed Morphological Pro-perties of Nanoparticles from Gasoline Direct Injection Engine Combustion of Ethanol Blends. SAE Technical Paper 2013-24-0185, Napoli, September 2013 .

Andreas Mayer, MEng. - Technik Thermische Maschinen (TTM), Switzerland.

Inż. Andreas Mayer-pracownik Termodynamicznej Techniki Maszyn (TTM), Szwajcaria. e-mail: ttm.a.mayer@bluewin.ch

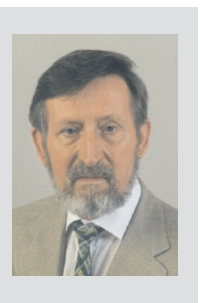

Alejandro Keller, DEng. - School of Engineering, Institute of Aerosol and Sensor Technology

Dr Alejandro Keller - Instytut Technologii Aerozoli oraz Czujników, Windisch, Szwajcaria.

e-mail:alejandro.keller@fhnw.ch 